\title{
Evaluation of "C" Values to Head Loss and Water Pressure Due to Pipe Aging: Case Study of Uni-Central Sarawak
}

\author{
King Kuok Kuok ${ }^{1 *}$, Po Chan Chiu ${ }^{2}$, Danny Chee Ming Ting ${ }^{1}$ \\ ${ }^{1}$ Faculty of Engineering, Computing and Science, Swinburne University of Technology Sarawak Campus, Kuching, \\ Sarawak, Malaysia \\ ${ }^{2}$ Faculty of Computer Science and Information Technology, Universiti Malaysia Sarawak, Kota Samarahan, \\ Sarawak, Malaysia \\ Email: ^kkuok@swinburne.edu.my
}

How to cite this paper: Kuok, K.K., Chiu, P.C. and Ting, D.C.M. (2020) Evaluation of "C" Values to Head Loss and Water Pressure Due to Pipe Aging: Case Study of Uni-Central Sarawak. Journal of Water Resource and Protection, 12, 1077-1088. https://doi.org/10.4236/jwarp.2020.1212064

Received: June 24, 2020

Accepted: December 20, 2020

Published: December 23, 2020

Copyright $\odot 2020$ by author(s) and Scientific Research Publishing Inc. This work is licensed under the Creative Commons Attribution International License (CC BY 4.0).

http://creativecommons.org/licenses/by/4.0/

\section{(c) (i) Open Access}

\begin{abstract}
Samarahan has transformed from a small village into education hub for the past 2 decades. Rapid development and population growth had led to speedy growth in water demand. The situation is getting worse as the pipes are deteriorating due to pipe aging. Therefore, there is a need to study the adequacy of water supply and relationships among roughness coefficient $(C)$ values in Hazen Williams' Equation with head loss and water pressure due to pipe aging at Uni-Central, a residential area located at Samarahan Sarawak. Investigations were carried out with Ductile Iron, Abestos Cement and Cast Iron pipes at age categories of 0 - 10 years, 10 - 30 years, 30 - 50 years, 50 - 70 years and $>70$ years. Six critical nodes named as A, B, C, D, E and F were identified to study the water pressure and head loss. Model was developed with InfoWorks Water Supply (WS) Pro software. The impact of pipe aging and materials to water pressure and head loss was not significant at Nodes A, B, C and F. However, max water pressure at Nodes D and F were only reaching $6.30 \mathrm{~m}$ and $7.30 \mathrm{~m}$, respectively for all investigations. Therefore, some improvement works are required. Results also show that Asbestos Cement pipe has the least impact on the head loss and water pressure, followed by Ductile Iron pipe and lastly Cast Iron pipe. Simulation results also revealed that older pipes have higher roughness coefficients, indicated with lower " $\mathrm{C}$ " values, thus increase the head loss and reduce the water pressure. In contrast, as "C" values increased, head loss will be reduced and water pressure will be increased.
\end{abstract}

\section{Keywords}

InfoWorks Water Supply (WS) Pro, Pressure Head, Hazen-Williams Equation, Head Loss 


\section{Introduction}

Sarawak, the largest state in Malaysia, had experienced a massive development in the past 2 decades especially Kota Samarahan, the state education hub which is only 20 minutes from Kuching City, the state capital. Due to ever-growing water demand and climate change, some areas in Kuching and Samarahan divisions are facing water shortages especially during drought season. Currently, about 98\% of water supply for Kuching and Samarahan Divisions is treated at Batu Kitang water treatment plant (BKWTP). BKWTP is operated by Kuching Water Board (KWB), which consists of four plants and eight modules with a total daily capacity of 580 Megalitres per day (MLD) [1].

Since last two decades, Kota Samarahan has transformed from a small village into education hub with the construction of two public Universities, institutions, training centres, academy buildings, residence houses, commercial shoplots, offices and roads to meet the needs of growing population [2] [3]. The rapid population growth had led to speedy growth in water demand. Metropolitan planning and development are becoming more convincing due to the point of increasing competition for water that leads to a contradictory demand. As a result, Samarahan now is facing insufficient of water supply and low water pressures [4]. The situation may worsen as the pipe internal surface roughness increases due to pipe aging.

Therefore, it is initiated in this study to investigate the adequacy of water supply at Uni-Central, Kota Samarahan Sarawak. The study will be further carried using three different piping materials named as Ductile Iron, Abestos Cement and Cast Iron pipes at 5 different age categories labelled as 0 - 10 years, $10-30$ years, 30 - 50 years, 50 - 70 years and $>70$ years. Different pipe materials and different pipe ages will have different roughness coefficient (C) values in Hazen Williams' Equation [5] [6]. These " $\mathrm{C}$ " values will govern water pressure and head loss within a reticulation system.

Investigation will be carried out using InfoWorks Water Supply (WS) Pro engine, introduced in 1998 by HR Wallingford software for comprehensive water distribution modelling of a water supply system [7]. InfoWorks WS is a hydrodynamic modeling software that is able to determine the appropriate pipe size and water pressure to meet the ever-growing water demand. It is a powerful, strong, proficient and extremely fast hydraulic simulation engine, specifically for very large networks [7] and successfully model various distribution networks projects [8] [9] [10] [11] [12]. Besides, it also combined with an influential Hydraulic engine, relational database and three-dimensional analysis tools by providing a single application in integrating flexible water supply system modelling with the necessity of asset management and business planning.

\section{Study Area}

Samarahan is the main education hub for Sarawak State and officially known as "Town of Knowledge". For the past 20 years, Samarahan had emerged from a 
small trading village into an educational hub. Higher learning Institutions in the area includes Universiti Malaysia Sarawak, two campuses of Universiti Teknologi MARA Kota Samarahan, Institute of Teacher Education Tun Abdul Razak Campus, Kota Samarahan Industrial Training Institute (ILPKS), INTAN training college and AAA Zenith Services Sdn Bhd, English language service provider. Heart Centre for Sarawak General Hospital, worth approximately RM 400 millions, is equipped with highly skilled cardiac specialist, modern and latest technology [13]. Other than that, Universiti Malaysia Sarawak (UNIMAS) has proposed to build a teaching hospital for its Medicine and Health Sciences Faculty under the 10th Malaysia Plan.

The population Samarahan Division has grown drastically from 197,220 in year 2000 to 250,622 in year 2010 [14]. For accommodating the ever-growing population, Samarahan had developed rapidly over the past ten years with many constructions, including higher institutions, academy buildings, residence houses, offices and roads. Other than that, the topographic of Samarahan basically are non-hilly, low-lying and flat, covered with peat soils which are ideal for coconut, oil palm and pineapples plantation [15].

The selected study area is Uni-Central, located in Samarahan Division. Uni-Central is a fast developing residential area with upcoming new developments. In this study, InfoWorks WS will be used to investigate water supply system at Uni-Central. Six critical nodes named as A, B, C, D, E and F as presented in Figure 1, have been identified to study the water pressure as well as the head loss. Node A is selected since it indicates water pressure at the starting point of the pipeline. Water pressure and head loss at Nodes B, C and D are investigated as there are the intersecting points, and Node $\mathrm{F}$ is the ending point of water reticulation system for the studied area.

\section{Methodology}

The process for model development is presented in Figure 2. Data collected from Kuching Water Board are including daily water pressure chart for Uni-Central in July 2020, pipe material and sizes as presented in Figure 3 and

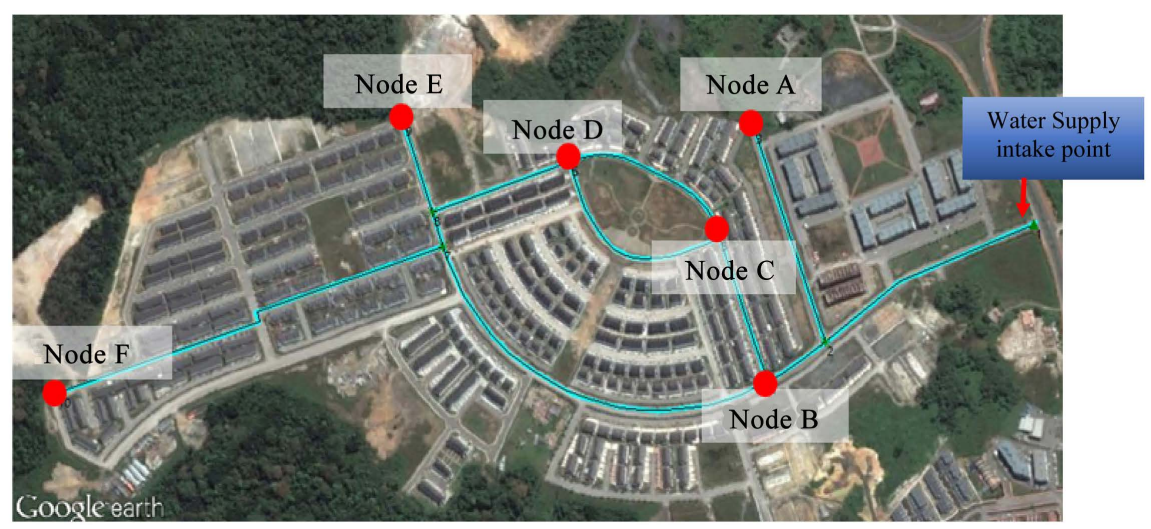

Figure 1. Water pipeline with critical nodes at Taman Uni-Central. 


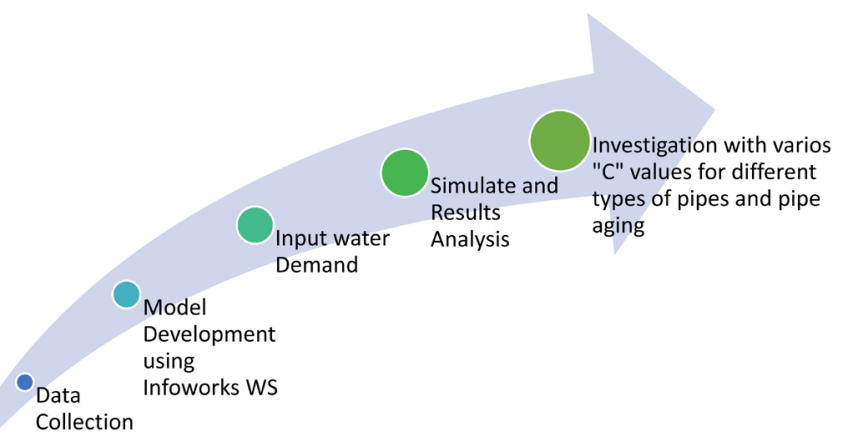

Figure 2. Flowchart of methodology.

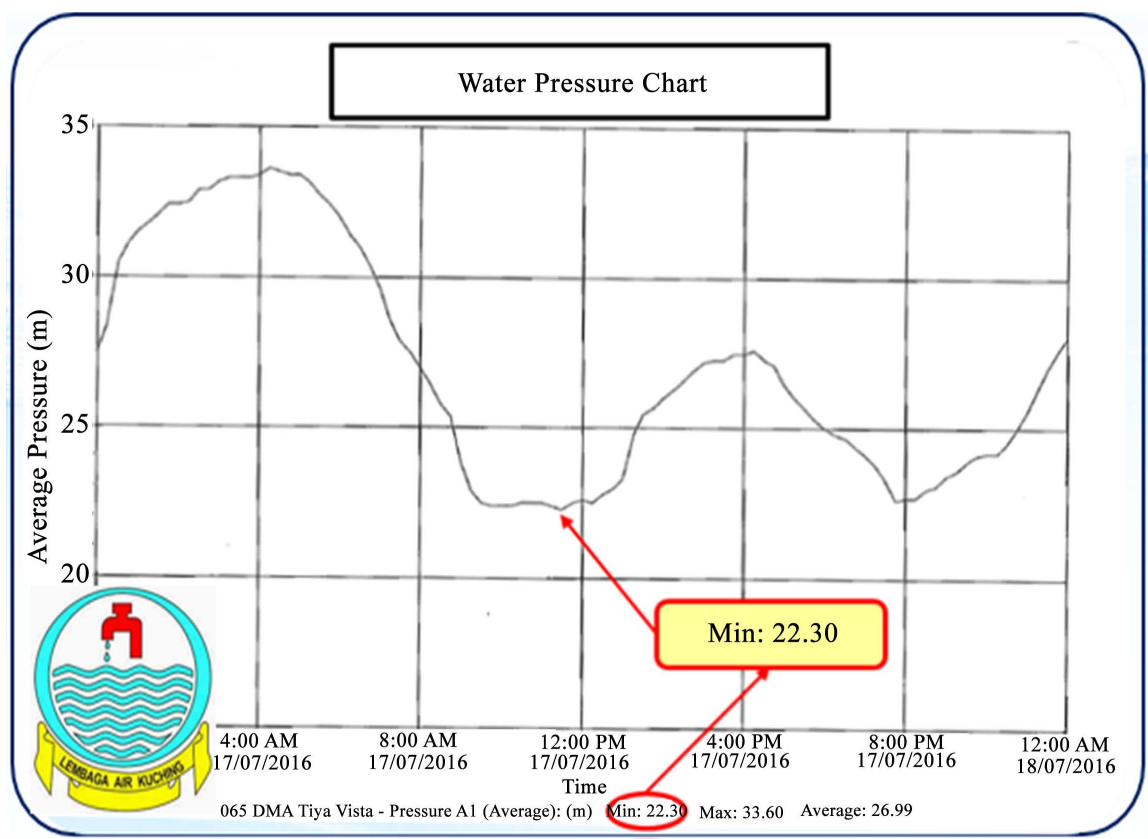

Figure 3. Water pressure chart [16].

Figure 4 respectively. The minimum daily water pressure for Uni-Central was found to be $22.30 \mathrm{~m}$. The existing pipe sizes installed within Uni-Central are 200 $\mathrm{mm}, 250 \mathrm{~mm}$ and $300 \mathrm{~mm}$ ductile iron pipes.

Guidelines of water demand rates for different type of houses are referring to Malaysian Water Association, as presented in Figure 5. The existing number of houses and shop houses for Uni-central were found to be 784 units of double-storey houses, 414 units of single-storey houses, 74 units of semi-detached houses and 100 units of 3-Storey shop houses.

All these information will be input into Infoworks WS for model development. The model development started with creating fixed Head to assign the water pressure head at the water intake point, followed by node creation cum with elevation, link creation for linking each node, and lastly inputting the water demand. The created water reticulation networks will be calibrated and validated, followed with simulation. 


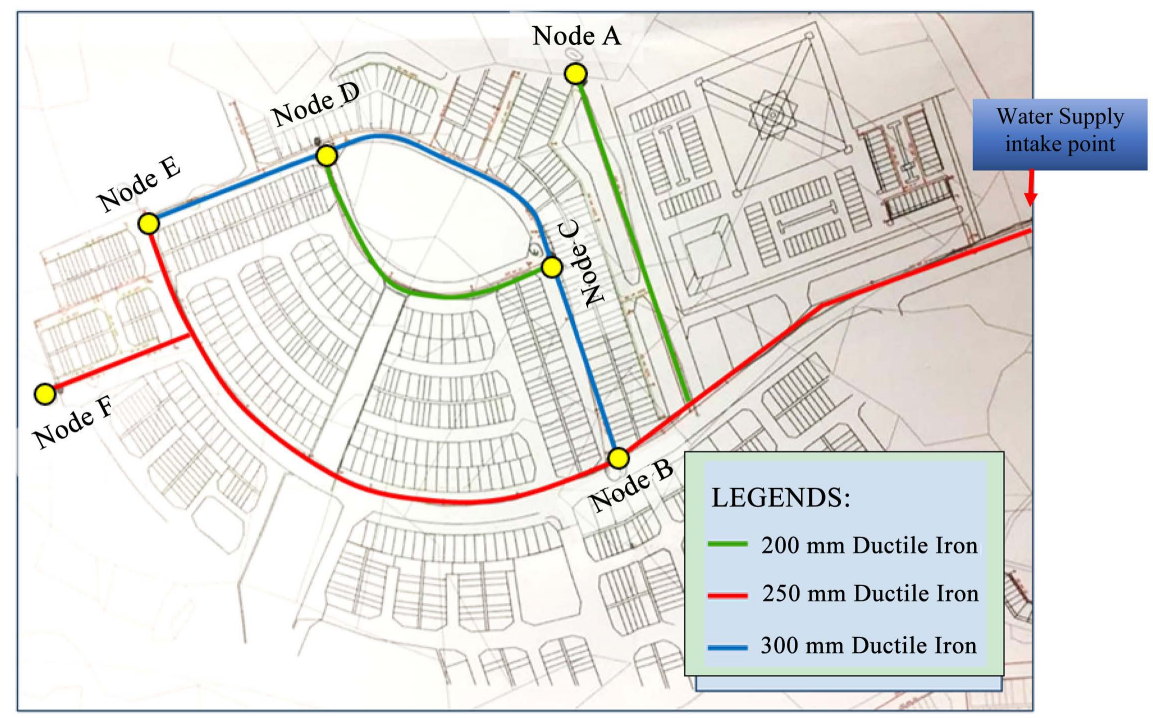

Figure 4. Engineering drawing on existing pipe material and pipe sizes [16].

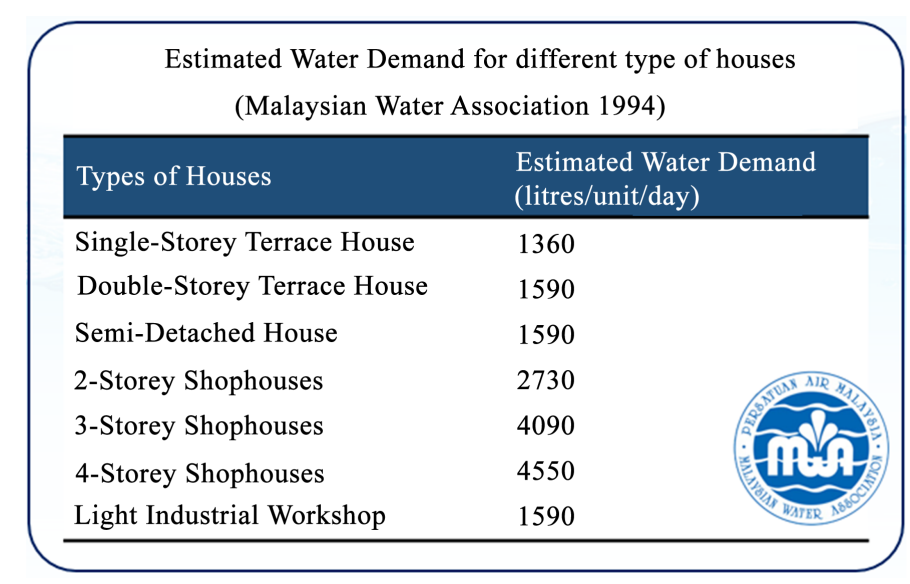

Figure 5. Estimated water demand for different type of properties [17].

Investigations will further carry out to determine the impact of " $\mathrm{C}$ " values in Hazen Williams' Equation to head loss and water pressure for different pipe materials and pipe aging as presented in Figure 6. It was found that the "C" values will change due to pipe aging for different pipe materials. Therefore, investigations will be carried out for ductile iron, asbestos cement and cast iron pipes, at five different age categories named as 0 to 10 years, 10 to 30 years, 30 to 50 years, 50 to 70 years and above 70 years. Head loss equation for Hazen Williams' Equation is presented in Equation (1) and Equation (2).

$$
\begin{gathered}
Q=1.318 C A R^{0.63} S^{0.54} \\
h_{f}=\left(4.73 L / C^{1.852} D^{4.87}\right) Q^{1.8152}
\end{gathered}
$$

where:

$$
\begin{aligned}
& Q=\text { flow, in } \mathrm{ft}^{3} / \mathrm{s} \mathrm{or}^{3} / \mathrm{s} \\
& C=\text { Hazen William roughness coefficient } \\
& A=\text { cross sectional area, in } \mathrm{ft}^{2} \text { or } \mathrm{m}^{2}
\end{aligned}
$$




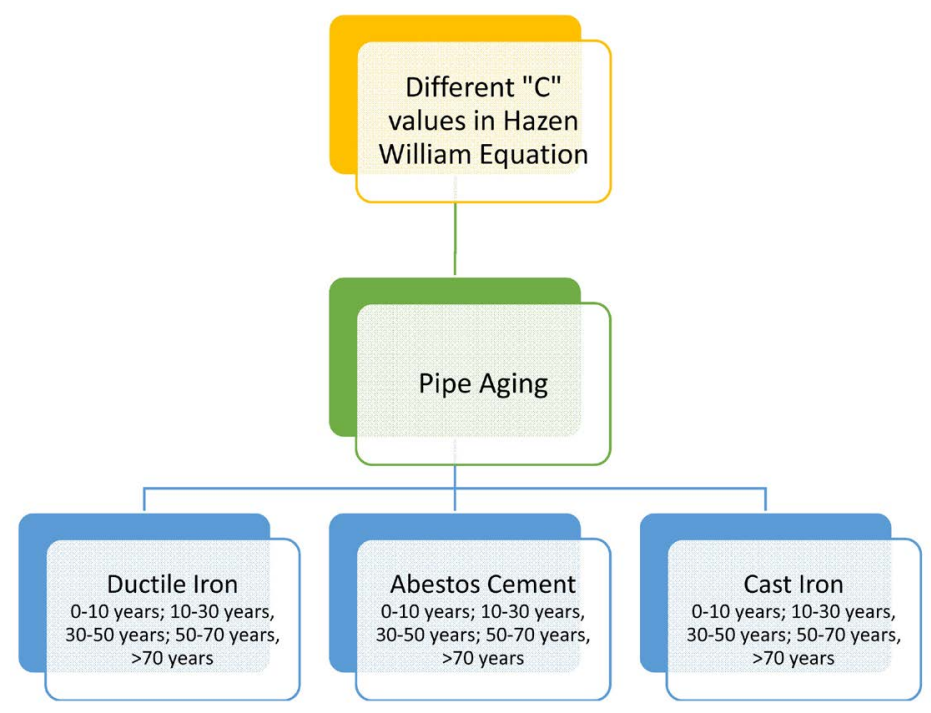

Figure 6. Investigation of "C" values on water pressure and head loss.

$R=$ hydraulic radius, in $\mathrm{m}$

$S=$ slope of energy grade line $\left(h_{f} / L\right)$

$L=$ pipe length, in $\mathrm{m}$

$D=$ pipe diameter, in $\mathrm{m}$

\section{Result and Discussion}

Results for water pressure and head loss for six critical nodes that identified as Node A, B, C, D, E and F for Ductile Iron, Abestos Cement and Cast Iron due to pipe aging at different pipe ages will be discussed in this section. All these " $\mathrm{C}$ " values are available in InfoWorks WS Pro v 4.0 software [7]. It was observed that nominal diameter of $200 \mathrm{~mm}$ and $225 \mathrm{~mm}$ are having the same " $\mathrm{C}$ " values at different aging period. This is because nominal diameter of $225 \mathrm{~mm}$ is only slightly larger than $200 \mathrm{~mm}$, and both are categorized as small pipe sizes that will reduce the water pressure and increase the head loss significantly due to pipe aging.

\section{- DUCTILE IRON PIPE}

Table 1 presents different " $C$ " values for ductile iron pipes with the size of 200 $\mathrm{mm}, 225 \mathrm{~mm}, 250 \mathrm{~mm}$ and $300 \mathrm{~mm}$ at different pipe ages.

Result for ductile iron pipe shows that "C" Hazen Williams roughness coefficient of different pipe ages will affect the minimum water pressure, where else the maximum water pressure is maintained as presented in Table 2. During peak hour of water usage, Node A has a minimum water pressure of $18.25 \mathrm{~m}$ for pipe age of 0 - 10 years, $18.24 \mathrm{~m}$ minimum water pressure for pipe age $10-30$ years, $18.22 \mathrm{~m}$ for pipe age of $30-50$ years, $18.21 \mathrm{~m}$ for pipe age of $50-70$ years and further reduced to $18.20 \mathrm{~m}$ for pipe age more than 70 years. A similar phenomenon is repeated at Node B, C, D, E and F. These revealed that minimum water pressure will be reduced gradually as the pipe is getting older with decreasing "C" values. 
Table 1. Ductile iron "C" values at different ages [18].

\begin{tabular}{cccccc}
\hline \multirow{2}{*}{ Nominal diameter $(\mathrm{mm})$} & \multicolumn{5}{c}{ Age (years) } \\
\cline { 2 - 6 } & $\mathbf{0}-\mathbf{1 0}$ & $\mathbf{1 0 - 3 0}$ & $\mathbf{3 0 - 5 0}$ & $\mathbf{5 0 - 7 0}$ & $>\mathbf{7 0}$ \\
\hline 300 & 125 & 110 & 95 & 90 & 85 \\
250 & 125 & 110 & 95 & 90 & 85 \\
225,200 & 120 & 105 & 95 & 85 & 80 \\
\hline
\end{tabular}

Table 2. Maximum and minimum water pressure $(\mathrm{m})$ of Ductile Iron pipe due to pipe aging.

\begin{tabular}{|c|c|c|c|c|c|c|c|c|c|c|}
\hline \multirow{3}{*}{ Node } & \multicolumn{10}{|c|}{ Age (years) } \\
\hline & \multicolumn{2}{|c|}{$0-10$} & \multicolumn{2}{|c|}{$10-30$} & \multicolumn{2}{|c|}{$30-50$} & \multicolumn{2}{|c|}{$50-70$} & \multicolumn{2}{|c|}{$>70$} \\
\hline & $\operatorname{Max}$ & $\min$ & $\max$ & $\min$ & $\max$ & $\min$ & $\max$ & $\min$ & $\max$ & $\min$ \\
\hline A & 18.30 & 18.25 & 18.30 & 18.24 & 18.30 & 18.22 & 18.30 & 18.21 & 18.30 & 18.20 \\
\hline B & 12.30 & 12.24 & 12.30 & 12.22 & 12.30 & 12.20 & 12.30 & 12.19 & 12.30 & 12.17 \\
\hline $\mathrm{C}$ & 16.30 & 16.23 & 16.30 & 16.21 & 16.30 & 16.18 & 16.30 & 16.16 & 16.30 & 16.15 \\
\hline $\mathrm{D}$ & 6.30 & 6.22 & 6.30 & 6.20 & 6.30 & 6.17 & 6.30 & 6.16 & 6.30 & 6.14 \\
\hline E & 7.30 & 7.22 & 7.30 & 7.20 & 7.30 & 7.17 & 7.30 & 7.15 & 7.30 & 7.14 \\
\hline $\mathrm{F}$ & 16.30 & 16.19 & 16.30 & 16.16 & 16.30 & 16.12 & 16.30 & 16.09 & 16.30 & 16.07 \\
\hline
\end{tabular}

Table 3 shows that "C" Hazen Williams roughness coefficient of different pipe ages has significant impact to maximum and minimum head loss of water reticulation system. Result shows that at pipe age of $0-10$ years, Node A has a maximum and minimum head loss of $0.00066 \mathrm{~m}$ and $0.000003 \mathrm{~m}$ respectively. As the pipe age increase to 10 - 30 years, maximum head loss will increase to $0.00085 \mathrm{~m}$ and minimum head loss still maintained at $0.000003 \mathrm{~m}$. At pipe age of 30 - 50 years, maximum and minimum head losses will increase to $0.00100 \mathrm{~m}$ and $0.000004 \mathrm{~m}$ respectively. The maximum and minimum head losses will further increase to $0.00120 \mathrm{~m}$ and $0.000005 \mathrm{~m}$ respectively at pipe age of $50-70$ years, and $0.00140 \mathrm{~m}$ and $0.000050 \mathrm{~m}$ for pipe age more than 70 years. Similar results were obtained for Nodes B, C, D and E. The simulation results revealed as the " $C$ " values is reducing due to pipe aging, maximum and minimum head losses will increase. As a result, the minimum water pressure will reduce due to the increment of head losses.

\section{- ABESTOS CEMENT PIPE}

Table 4 presents different "C" values for abestos cement pipes with the size of $200 \mathrm{~mm}, 225 \mathrm{~mm}, 250 \mathrm{~mm}$ and $300 \mathrm{~mm}$ at different pipe ages.

Result for asbestos cement pipe revealed that "C" values have significant impact to minimum pipe pressure at different pipe ages, but not the maximum water pressure. Table 5 shows Node A has a minimum water pressure of $18.25 \mathrm{~m}$ for asbestos cement pipe age of 0 - 10 years during peak hour of water usage. However, as asbestos cement pipe used for 10 - 30 years, the minimum water pressure will reduce to $18.24,18.23 \mathrm{~m}$ for pipe age of $30-50$ years, $18.22 \mathrm{~m}$ for pipe 
Table 3. Maximum and minimum head loss (m) of ductile iron pipe due to pipe aging.

\begin{tabular}{|c|c|c|c|c|c|c|c|c|c|c|}
\hline \multirow{3}{*}{ Node } & \multicolumn{10}{|c|}{ Age (years) } \\
\hline & \multicolumn{2}{|c|}{$0-10$} & \multicolumn{2}{|c|}{$10-30$} & \multicolumn{2}{|c|}{$30-50$} & \multicolumn{2}{|c|}{$50-70$} & \multicolumn{2}{|c|}{$>70$} \\
\hline & $\max$ & $\min$ & $\max$ & $\min$ & $\max$ & $\min$ & $\max$ & $\min$ & $\max$ & $\min$ \\
\hline A & 0.00066 & 0.000003 & 0.00085 & 0.000003 & 0.00100 & 0.000004 & 0.00120 & 0.000005 & 0.00140 & 0.000050 \\
\hline B & 0.01300 & 0.000049 & 0.01600 & 0.000062 & 0.02100 & 0.000100 & 0.02400 & 0.000100 & 0.02600 & 0.000110 \\
\hline C & 0.01200 & 0.000046 & 0.01500 & 0.000061 & 0.02000 & 0.000076 & 0.02100 & 0.000092 & 0.02400 & 0.000093 \\
\hline D & 0.00330 & 0.000130 & 0.00420 & 0.000016 & 0.00540 & 0.000022 & 0.00610 & 0.000026 & 0.00680 & 0.000029 \\
\hline E & 0.00012 & 0.000001 & 0.00015 & 0.000001 & 0.00020 & 0.000001 & 0.00022 & 0.000001 & 0.00024 & 0.000001 \\
\hline $\mathrm{F}$ & 0.03300 & 0.000140 & 0.04300 & 0.000180 & 0.05100 & 0.000250 & 0.06300 & 0.000290 & 0.07100 & 0.000300 \\
\hline
\end{tabular}

Table 4. Asbestos cement "C" values with different ages [18].

\begin{tabular}{cccccc}
\hline \multirow{2}{*}{ Nominal diameter (mm) } & \multicolumn{5}{c}{ Age (years) } \\
\cline { 2 - 6 } & $\mathbf{0 - 1 0}$ & $\mathbf{1 0 - 3 0}$ & $\mathbf{3 0 - 5 0}$ & $\mathbf{5 0 - 7 0}$ & $>70$ \\
\hline 300 & 130 & 115 & 100 & 95 & 90 \\
250 & 130 & 115 & 100 & 95 & 90 \\
225,200 & 125 & 110 & 100 & 90 & 85 \\
\hline
\end{tabular}

Table 5. Maximum and minimum water pressure (m) of asbestos cement pipe due to pipe aging.

\begin{tabular}{cccccccccccc}
\hline & \multicolumn{7}{c}{ Age (years) } \\
\cline { 2 - 11 } Node & \multicolumn{1}{c}{$\mathbf{0}-\mathbf{1 0}$} & \multicolumn{1}{c}{$10-\mathbf{3 0}$} & \multicolumn{2}{c}{$\mathbf{3 0}-\mathbf{5 0}$} & \multicolumn{2}{c}{$\mathbf{5 0}-\mathbf{7 0}$} & \multicolumn{2}{c}{$>70$} \\
\cline { 2 - 11 } & $\max$ & $\min$ & $\max$ & $\min$ & $\max$ & $\min$ & $\max$ & $\min$ & $\max$ & $\min$ \\
\hline A & 18.30 & 18.25 & 18.30 & 18.24 & 18.30 & 18.23 & 18.30 & 18.22 & 18.30 & 18.21 \\
B & 12.30 & 12.24 & 12.30 & 12.23 & 12.30 & 12.21 & 12.30 & 12.20 & 12.30 & 12.19 \\
C & 16.30 & 16.23 & 16.30 & 16.21 & 16.30 & 16.19 & 16.30 & 16.18 & 16.30 & 16.16 \\
D & 6.30 & 6.23 & 6.30 & 6.21 & 6.30 & 6.18 & 6.30 & 6.17 & 6.30 & 6.16 \\
E & 7.30 & 7.23 & 7.30 & 7.21 & 7.30 & 7.18 & 7.30 & 7.17 & 7.30 & 7.15 \\
F & 16.30 & 16.20 & 16.30 & 16.17 & 16.30 & 16.13 & 16.30 & 16.11 & 16.30 & 16.09 \\
\hline
\end{tabular}

age of 50 - 70 years and further reduced to $18.20 \mathrm{~m}$ for pipe age more than 70 years. This phenomenon is repeated at Nodes B, C, D, E and F.

Table 6 presents maximum and minimum head losses at Nodes A, B, C, D, E and $\mathrm{F}$ due to pipe aging for asbestos cement pipeline. When the pipelines are still new at $0-10$ years, Node A has a maximum and minimum head loss of 0.00061 $\mathrm{m}$ and $0.000003 \mathrm{~m}$ respectively. As the pipe age increase to $10-30$ years, maximum and minimum head losses will increase to $0.00078 \mathrm{~m}$ and $0.00003 \mathrm{~m}$ respectively. At pipe age of 30 - 50 years, maximum and minimum head losses will yield to $0.00093 \mathrm{~m}$ and $0.00004 \mathrm{~m}$ respectively, $0.00110 \mathrm{~m}$ and $0.00005 \mathrm{~m}$ for pipe age of $50-70$ years, $0.00120 \mathrm{~m}$ and $0.00049 \mathrm{~m}$ for pipe age more than 70 
years. Similar results were obtained for Nodes B, C, D, E and F, where both maximum and minimum head losses values will increase as the pipe age getting older. The simulation results showed that as the "C" values are reducing due to pipe aging, head losses will increase.

\section{- CAST IRON PIPE}

Table 7 presents different "C" values for cast iron pipes with the size of 200 $\mathrm{mm}, 225 \mathrm{~mm}, 250 \mathrm{~mm}$ and $300 \mathrm{~mm}$ at different pipe ages.

Table 8 presents the water pressure simulation result for cast iron pipe with different " $C$ " values due to pipe aging. Node A has a minimum water pressure of $18.25 \mathrm{~m}$ for pipe age of $0-10$ years during peak hour. Minimum water pressure was reduced to $18.23 \mathrm{~m}$ for pipe age 10 - 30 years, $18.21 \mathrm{~m}$ for pipe age of 30 - 50 years, $18.20 \mathrm{~m}$ for pipe age of $50-70$ years and $18.19 \mathrm{~m}$ for pipe age more than 70 years. Nodes B, C, D, E and F also having similar water pressure reduction as the cast iron pipes get older. However, maximum water pressure is not affected due to pipe aging. Results revealed that minimum water pressure will be reduced gradually as the pipe is getting older.

The impact of "C" values to head loss for cast iron pipe due to aging is represented in Table 9. Result obtained indicates that Node A has a maximum and minimum head loss of $0.00071 \mathrm{~m}$ and $0.000003 \mathrm{~m}$ respectively for pipe age of 0 10 years. For pipe age of 10 - 30 years, maximum head will increase to $0.00093 \mathrm{~m}$ and minimum head loss will slightly increase to $0.000004 \mathrm{~m}$. Maximum and minimum head losses will increased to $0.00110 \mathrm{~m}$ and $0.000004 \mathrm{~m}$ respectively

Table 6. Maximum and minimum head losses $(\mathrm{m})$ of asbestos cement pipe due to pipe aging.

\begin{tabular}{|c|c|c|c|c|c|c|c|c|c|c|}
\hline \multirow{3}{*}{ Node } & \multicolumn{10}{|c|}{ Age (years) } \\
\hline & \multicolumn{2}{|c|}{$0-10$} & \multicolumn{2}{|c|}{$10-30$} & \multicolumn{2}{|c|}{$30-50$} & \multicolumn{2}{|c|}{$50-70$} & \multicolumn{2}{|c|}{$>70$} \\
\hline & $\max$ & $\min$ & $\max$ & $\min$ & $\max$ & $\min$ & $\max$ & $\min$ & $\max$ & $\min$ \\
\hline A & 0.00061 & 0.00003 & 0.00078 & 0.00003 & 0.00093 & 0.00004 & 0.00110 & 0.00005 & 0.00120 & 0.00049 \\
\hline B & 0.01200 & 0.00038 & 0.01500 & 0.00055 & 0.01900 & 0.00085 & 0.02100 & 0.00100 & 0.02400 & 0.00110 \\
\hline $\mathrm{C}$ & 0.01100 & 0.00030 & 0.01400 & 0.00050 & 0.01800 & 0.00070 & 0.02000 & 0.00091 & 0.02200 & 0.00090 \\
\hline $\mathrm{D}$ & 0.00310 & 0.00310 & 0.00390 & 0.00014 & 0.00490 & 0.00015 & 0.00550 & 0.00025 & 0.00610 & 0.00026 \\
\hline $\mathrm{E}$ & 0.00011 & 0.00000 & 0.00014 & 0.00001 & 0.00018 & 0.00001 & 0.00020 & 0.00001 & 0.00022 & 0.00001 \\
\hline $\mathrm{F}$ & 0.03100 & 0.00110 & 0.03900 & 0.00170 & 0.04700 & 0.00220 & 0.05700 & 0.00260 & 0.06300 & 0.00300 \\
\hline
\end{tabular}

Table 7. Cast iron "c" values with different ages [18].

\begin{tabular}{cccccc}
\hline \multirow{2}{*}{ Nominal diameter $(\mathrm{mm})$} & \multicolumn{5}{c}{ Age (years) } \\
\cline { 2 - 6 } & $\mathbf{0 - 1 0}$ & $\mathbf{1 0 - 3 0}$ & $\mathbf{3 0 - 5 0}$ & $\mathbf{5 0 - 7 0}$ & $>\mathbf{7 0}$ \\
\hline 300 & 120 & 105 & 90 & 85 & 80 \\
250 & 120 & 105 & 90 & 85 & 80 \\
225,200 & 115 & 100 & 90 & 80 & 75 \\
\hline
\end{tabular}


Table 8. Maximum and minimum water pressure $(\mathrm{m})$ of cast iron pipe due to pipe aging.

\begin{tabular}{cccccccccccc}
\hline & \multicolumn{10}{c}{ Age (years) } \\
\cline { 2 - 12 } & \multicolumn{2}{c}{$\mathbf{0}-\mathbf{1 0}$} & \multicolumn{1}{c}{$10-\mathbf{3 0}$} & \multicolumn{2}{c}{$\mathbf{3 0}-\mathbf{5 0}$} & \multicolumn{2}{c}{$\mathbf{5 0}-\mathbf{7 0}$} & \multicolumn{2}{c}{$>$ 70 } \\
\hline A & 18.30 & 18.25 & 18.30 & 18.23 & 18.30 & 18.21 & 18.30 & 18.20 & 18.30 & 18.19 \\
B & 12.30 & 12.23 & 12.30 & 12.21 & 12.30 & 12.19 & 12.30 & 12.17 & 12.30 & 12.16 \\
C & 16.30 & 16.22 & 16.30 & 16.20 & 16.30 & 16.16 & 16.30 & 16.15 & 16.30 & 16.13 \\
D & 6.30 & 6.22 & 6.30 & 6.19 & 6.30 & 6.16 & 6.30 & 6.14 & 6.30 & 6.12 \\
E & 7.30 & 7.21 & 7.30 & 7.19 & 7.30 & 7.15 & 7.30 & 7.14 & 7.30 & 7.12 \\
F & 16.30 & 16.18 & 16.30 & 16.14 & 16.30 & 16.10 & 16.30 & 16.07 & 16.30 & 16.04 \\
\hline
\end{tabular}

Table 9. Maximum and minimum head losses (m) of cast iron pipe due to pipe aging.

\begin{tabular}{|c|c|c|c|c|c|c|c|c|c|c|}
\hline \multirow{3}{*}{ Node } & \multicolumn{10}{|c|}{ Age (years) } \\
\hline & \multicolumn{2}{|c|}{$0-10$} & \multicolumn{2}{|c|}{$10-30$} & \multicolumn{2}{|c|}{$30-50$} & \multicolumn{2}{|c|}{$50-70$} & \multicolumn{2}{|c|}{$>70$} \\
\hline & $\max$ & $\min$ & $\max$ & $\min$ & $\max$ & $\min$ & $\max$ & $\min$ & $\max$ & $\min$ \\
\hline A & 0.00071 & 0.000003 & 0.00093 & 0.000004 & 0.00110 & 0.000004 & 0.00140 & 0.000005 & 0.00160 & 0.000050 \\
\hline B & 0.01400 & 0.000053 & 0.01800 & 0.000075 & 0.02400 & 0.000090 & 0.02600 & 0.000100 & 0.02900 & 0.000120 \\
\hline $\mathrm{C}$ & 0.01300 & 0.000052 & 0.01600 & 0.000067 & 0.02200 & 0.000092 & 0.02400 & 0.000093 & 0.02700 & 0.000100 \\
\hline $\mathrm{D}$ & 0.00360 & 0.000014 & 0.00460 & 0.000018 & 0.00590 & 0.000032 & 0.00680 & 0.000031 & 0.00770 & 0.000030 \\
\hline E & 0.00013 & 0.000000 & 0.00017 & 0.000001 & 0.00022 & 0.000001 & 0.00024 & 0.000001 & 0.00028 & 0.000001 \\
\hline F & 0.03600 & 0.000150 & 0.04700 & 0.000180 & 0.05700 & 0.000230 & 0.07100 & 0.000270 & 0.08000 & 0.000300 \\
\hline
\end{tabular}

for pipe age of 30 - 50 years. At pipe age of 50 - 70 years, maximum and minimum head losses will yield to $0.00140 \mathrm{~m}$ and $0.000005 \mathrm{~m}$ respectively. The highest maximum and minimum head losses will reach the peak when pipe age is more than 70 years with $0.00160 \mathrm{~m}$ and $0.000050 \mathrm{~m}$ respectively. Nodes $\mathrm{B}, \mathrm{C}, \mathrm{D}$ and $\mathrm{E}$ are having similar results trend with Node A.

\section{Conclusions}

This study demonstrated the relationship among " $\mathrm{C}$ " Hazen Williams roughness coefficient, head loss and water pressure. Simulation results obtained revealed that as the pipe used for a longer period, internal surface pipe roughness will increase and " $\mathrm{C}$ " values will be reduced. " $\mathrm{C}$ " value is inversely proportional to the head loss. Therefore, reduction of " $\mathrm{C}$ " values will lead to the increment of head loss. As the head loss value is increasing, the water pressure within a pipeline will be reduced. In contrast, as " $\mathrm{C}$ " values increased, head loss will be reduced and water pressure will be increased.

The analysis of pipe aging to water pressure as well as head loss is not significant at Nodes A, B, C and F. The water pressures were found to be adequate even when pipe age is more than 70 years. This is because the designed pipe length is too short with the total length of $3.6 \mathrm{~km}$ and the effect of friction loss is minimal. However, the water pressure at Nodes D and F is significantly reduced 
as the pipe length is longer. The water pressure was found to be less than $10 \mathrm{~m}$. Therefore, some improvement works need to be done such as constructing an elevated storage tank or using water pump to increase the water pressure delivered to household. It can be concluded that "C" Hazen Williams roughness coefficient of the pipe aging and materials is an essential factor and major contributor to the head loss and water pressure. It was found pipe materials also affected the head loss and water pressure within a piping system. Out of three types of piping materials, it was observed that Asbestos Cement pipe has the least impact on the head loss and water pressure, followed by Ductile Iron pipe and lastly Cast Iron pipe.

\section{Conflicts of Interest}

The authors declare no conflicts of interest regarding the publication of this paper.

\section{References}

[1] Kuok, K.K., Harun, S. and Chiu, P.C. (2011) A Review of Integrated River Basin Management for Sarawak River. American Journal of Environmental Sciences, 7, 276-285. https://doi.org/10.3844/ajessp.2011.276.285

[2] Zainudin, S.R., Mustafa, K.A., Austin, D., Helmy, J. and Lingkeu, D.A. (2012) Urban Trees Diversity in Kuching North City and UNIMAS, Kota Samarahan, Sarawak. Universiti Putra Malaysia Press, Serdang.

[3] Kueh, S.M. and Kuok, K.K. (2016) Precipitation Downscaling Using the Artificial Neural Network BatNN and Development of Future Rainfall Intensity-DurationFrequency Curves. Climate Research, 68, 73-89. https://doi.org/10.3354/cr01383

[4] The Star Online (2014) Minister Advises Residents to Use Water Wisely Despite Rain Relief.

http://www.thestar.com.my/news/community/2014/08/05/minister-advises-resident s-to-use-water-wisely-despite-rain-relief/

[5] Jaćimović, N., Stamenić, M., Kolendić, P., Dordević, D., Radanov, B. and Vladić, L. (2015) A Novel Method for the Inclusion of Pipe Roughness in the Hazen-Williams Equation. FME Transactions, 43, 35-39. https://doi.org/10.5937/fmet1501035J

[6] Abbott, M.B. and Minns, A.W. (2017) Computational Hydraulics. Routledge, Abingdon. https://doi.org/10.4324/9781315259703

[7] Innovyze (2020) InfoWorks WS Pro: Improve Customer Service and Reduce Costs Advanced Hydraulic Modeling Software for Faster, More Rubust Analysis and Management of Water Supply Networks. https://www.innovyze.com/en-us/products/infoworks-ws-pro

[8] Water World Magazine (2009) Computers, Software and Automation: InfoWorks WS Assists Water Planning in Italian Alps. PennWell Corporation, Houston. https://www.waterworld.com/international/potable-water/article/16200549/comput ers-software-automation

[9] Mrdja, Z. (2007) Modeling Software Removes Guesswork from Water Utility Management. PennWell Corporation, Houston.

[10] Popovic, A. (2007) Modeling Software Aids Belgrade's Water Supply. PennWell Corporation, Houston. 
[11] Marinkovic, V. (2007) Water System Modeling Helps Determine Goals for Serbian Suburb. PennWell Corporation, Houston.

[12] Sonaje, N.P. and Joshi, M.G. (2015) Review of Modeling and Application of Water Distibution Networks (WDN) Softwares. International of Technical Research Applications, 3, 174-178.

[13] Kuok, K.K., Mah, Y.S., Imteaz, M.A., and Kueh, S.M. (2016) Comparison of Future Intensity Duration Frequency Curve by Considering the Impact of Climate Change: Case Study for Kuching City. International Journal of River Basin Management, 14, 47-55. https://doi.org/10.1080/15715124.2015.1082478

[14] Sarawak Population (2016) Official Website of Sarawak Government. http://www.sarawak.gov.my/web/home/article_view/240/175/

[15] Kuok, K.K. and Bessaih, N. (2007) Artificial Neural Networks (ANNS) for Daily Rainfall Runoff Modelling. The Institution of Engineers, Malaysia, 68, 31-42.

[16] KWB (2016) Water Pressure Chart for Uni-Central, Kota Samanrahan, Kuching Water Board.

[17] Malaysian Water Association (1994) MWA Design Guidelines for Water Supply Systems. The Malaysian Water Association, Malaysia.

[18] Innovyze (2019) InfoWorks WS Pro v 4.0 [Computer Software]. Portland (HQ), OR United States 6720 SW Macadam Ave 150. 